\author{
lek. med. Kinga GROBELSKA ${ }^{1}$ \\ dr Anna KRÓLIKOWSKA ${ }^{1}$ \\ mgr Ewa ZIELIŃSKI ${ }^{1}$ \\ dr Elżbieta NURCZYŃSKA ${ }^{1}$ \\ dr Jerzy TELAK ${ }^{2}$
}

Przyjęty/Accepted/Принята: 24.05.2013;

Zrecenzowany/Reviewed/Рецензирована: 31.03 .2014 ;

Opublikowany/Published/Опубликована: 30.06.2014;

\title{
ZATRUCIE TLENKIEM WĘGLA - ZADANIA RATOWNIKA NA MIEJSCU ZDARZENIA ${ }^{3}$
}

\author{
Carbon Monoxide Poisoning - Rescue Procedures
}

\section{Отравление угарным газом - задачи спасателя на месте происшествия}

\begin{abstract}
Abstrakt
Cel: Wskazanie optymalnego postępowania w przypadku zatrucia tlenkiem węgla.

Wprowadzenie: Co roku odnotowywanych jest wiele zdarzeń związanych z tlenkiem węgla, w wyniku których duża liczba osób zostaje poszkodowanych, a kilkadziesiąt umiera wskutek zaczadzenia. Intoksykacja tlenkiem węgla ma najczęściej charakter przypadkowy, zdarza się podczas pożarów lub wskutek nieprawidłowego działania systemów grzewczych lub systemów wentylacji. Tlenek węgla zajmuje pierwsze miejsce wśród gazów mogących stać się potencjalną przyczyną zgonu. CO to bezwonny, bezbarwny i niedrażniący gaz, szczególnie niebezpieczny, ponieważ niewyczuwalny. W przypadku zwiększonego stężenia CO w powietrzu łączy się on z hemoglobiną, mioglobiną, oksydazą cytochromową, wypierając z tych połączeń tlen. Właściwości tlenku węgla - szybkie i trwałe tworzenie karboksyhemoglobiny sprawiają, że w organizmie poszkodowanego dochodzi do ciężkiego niedotlenienia narządów, a w szczególności ośrodkowego układu krążenia i mięśnia sercowego. Utrata możliwości transportu tlenu przez krwinki czerwone powoduje niedotlenienie tkanek i narządów. W pracy, oprócz przyczyn i objawów zatruć tlenkiem węgla oraz mechanizmu jego toksyczności, zawarto schemat postępowania ratownika na miejscu zdarzenia, zwracając szczególną uwagę na znaczenie wczesnej tlenoterapii. Wyodrębniono trzy ścieżki czynności ratunkowych. Postępowanie z zatrutym przytomnym obejmuje zapewnienie dostępu świeżego powietrza, badanie BTLS i wstępne zaopatrzenie urazów zagrażających życiu. Zatruty nieprzytomny, który oddycha prawidłowo, wymaga po włączeniu tlenoterapii i zastosowaniu pozycji bocznej kontroli parametrów życiowych co 1-2 minuty. W przypadku braku oddechu u poszkodowanego nieprzytomnego ratownik podejmuje czynności resuscytacyjne według wytycznych 2010 Europejskiej Rady Resuscytacji. Nieswoistość objawów skutkuje niską rozpoznawalnością zatrucia CO, a często nakłada się na to niewłaściwe postępowanie z poszkodowanym na miejscu zdarzenia.

Metody: Analiza publikacji, dokumentów i danych statystycznych, badanie opinii z wykorzystaniem techniki wywiadu przeprowadzone w sposób jawny i otwarty.

Wnioski:

1. Tlenek węgla może być przyczyną groźnych zatruć.

2. Brak swoistych objawów zatrucia powoduje często błędy w diagnozie i leczeniu zatruć tlenkiem węgla.

3. Rozpoznanie zatrucia tlenkiem węgla powinno być rozważone u każdej ofiary pożaru.

4. Każdy ratownik powinien być przeszkolony w zakresie rozpoznawania i leczenia zatrucia tlenkiem węgla.
\end{abstract}

Słowa kluczowe: tlenek węla, zatrucie, tlenoterapia, ratownik, nieprzytomny, resuscytacja krążeniowo-oddechowa. Typ artykułu: artykuł przeglądowy

\footnotetext{
${ }^{1}$ Collegium Medicum w Bydgoszczy UMK w Toruniu, ul. Jagiellońska 13-15, 85-067 Bydgoszcz, kingro@wp.pl / Nicolaus Copernicus University Collegium Medicum in Bydgoszcz, Poland;

${ }^{2}$ Szkoła Główna Służby Pożarniczej w Warszawie, ul. Juliusza Słowackiego 52/54, Warszawa / The Main School of Fire Service, Warsaw, Poland;

${ }^{3}$ Autorzy wnieśli jednakowy wkład w powstanie artykułu/ The authors contributed equally to this paper;
} 


\begin{abstract}
Purpose: Providing an optimal procedure for carbon monoxide poisoning.

Introduction: Each year there are many cases of carbon monoxide poisoning registered in Poland. Numerous end up with the death of their victims. The intoxication with carbon monoxide is usually accidental. It occurs as a consequence of fires or due to improper operation of heating systems or ventilating ducts. Carbon monoxide is the most dangerous gas which constitutes a potential cause of deadly poisoning. Carbon monoxide is odourless, colourless, acrid and extremely dangerous, because of its imperceptibility. When the level of $\mathrm{CO}$ in the air increases, the gas connects with hemoglobin, myoglobin and cytochrome oxidase and displaces oxygen. Carbon monoxide properties, such as quick and permanent connection to hemoglobin cause severe hypoxia of internal organs, especially, central nervous system and heart. The lack of oxygen transport by red blood cells results in the hypoxia of organs and issues. Apart from causes and symptoms of carbon monoxide poisoning and the mechanism of its toxicity, this paper also presents an algorithm of rescue proceedings, with particular attention drawn to the importance of early oxygen therapy. Fresh air should be delivered to the conscious victim of CO poisoning, BTLS should be performed and a rescuer should also deal with life threatening injuries. Oxygen therapy, recovery position and control of life parameters should be applied in case when an unconscious victim is normally breathing. If he or she does not breathe, the rescuer should initiate life supporting procedures presented in Guidelines of European Resuscitation Council. The lack of typical symptoms of carbon monoxide poisoning often leads to a wrong diagnosis and results in inappropriate treatment of $\mathrm{CO}$ poisoning victims.

Methods: An analysis of publications, documents and statistics, opinion research with the use of an open survey.

Conclusions:

1. Carbon monoxide can be a cause of very dangerous poisoning.

2. The lack of typical symptoms may result in a wrong diagnosis and treatment of carbon monoxide poisoning.

3. Carbon monoxide poisoning should be taken into account as a potential diagnosis for every fire victim.

4. Every rescuer should be trained in diagnosing and treating carbon monoxide poisoning victim.
\end{abstract}

Keywords: carbon monoxide, poisoning, fire, oxygen therapy, rescuer, unconscious, cardio-pulmonary resuscitation Type of article: review article

\begin{abstract}
Аннотация
Цель: Определить правила поведения в случае отравления угарным газом.

Введение: Ежегодно фиксируется много происшествий, связанных с отравлением угарным газом, в результате которых большое количество людей получает отравление, а несколько десятков умирает от тяжёлого отравления угарным газом. Отравление угарным газом имеет, прежде всего, случайных характер, наступает во время пожаров или вследствие неправильной работы отопительных или вентиляционных систем.

Угарный газ занимает первое место среди газов, которые могут стать потенциальной причиной смерти. СО это бесцветный, нераздражающий и без запаха газ - особенно опасный, потому что является неощутимым. В случае повышенной концентрации СО в воздухе он связывается с гемоглобином, миоглобином, цитохром с-оксидазой - вытесняя из этих связей кислород. Свойства угарного газа - вызывают - быстрое и прочное образование карбоксигемоглобина и приводят к тяжелей гипоксии органов, в особенности центральной сердечно-сосудистой системы и сердечной мышцы. Потеря возможности транспортировки кислорода красными кровяными тельцами ведёт к гипоксии тканей и органов. В работе, кроме причин и признаков отравлений угарным газом и механизма его токсичности, была представлена схема поведения спасателя на месте происшествия, обращая особое внимание на значение неотложной кислородотерапии. Были выделены три случая для проведения спасательных работ. Поведение с потерпевшим находящимся в сознательном состоянии включает обеспечение доступа к свежему воздуху, исследование BTLS и вступительную перевязку травм угрожающих жизни. Отравленному, который потерял сознание, но который правильно дышит требуется, после начала оксигенотерапии и применения боковой позиции, проводить контроль жизненных параметров каждые 1-2 минуты. В случае отсутствия дыхания у пострадавшего потерявшего сознание, спасатель начинает ресусцитацию согласно указаний 2010 Европейского Совета Ресусцитации. Присутствие неспецифических признаков свидетельствует о низком уровне правильности диагноза отравления СО и часто сопровождается неправильным поведением с пострадавшим на месте происшествия.

Методы: анализ публикаций, документов, статистических данных, исследование мнений с использованием техники проведения явного и открытого интервью.

Выводы: 1. Угарный газ может стать причиной опасных отравлений.

2. Отсутствие типичных признаков отравления часто ведёт к ошибкам в диагнозе и лечении отравлений угарным газом.

3. Выявление отравления угарным газом должно проводиться у каждого пострадавшего от пожара.

4. Каждый спасатель должен быть обучен в области диагноза и лечения отравления угарным газом.
\end{abstract}

Ключевые слова: СО, отравление, терапия кислородом, спасатель, бессознательное состояние, сердечно-лёгочная реанимация Вид статьи: обзорная статья

\section{Wprowadzenie}

Główny Urząd Statystyczny podaje, że zatrucia i urazy znajdują się na trzecim miejscu wśród przyczyn zgonów w Polsce (po chorobach układu krążenia i chorobach nowotworowych). W 2011 roku odsetek zgonów spowodowanych urazami i zatruciami wyniósł ponad $6 \%$. Jednocześnie odnotowano wysoki udział zgonów, dla których przyczyna nie została dokładnie określona (ponad 6\%) [1]. Ostre zatrucia gazami najczęściej wywoływa- ne są tlenkiem węgla (CO). Według statystyk Komendy Głównej Państwowej Straży Pożarnej od września 2012 r. do 12 marca 2013 r. odnotowano 3388 zdarzeń związanych $\mathrm{z}$ tlenkiem węgla. Poszkodowane w nich zostały 1964 osoby, a na skutek zaczadzenia zginęło 86 osób [2]. Liczba zdarzeń związanych z działaniem tlenku węgla może być w rzeczywistości znacznie wyższa. Mimo licznych akcji prewencyjnych PSP niska świadomość społeczna, jak również trudności diagnostyczne powo- 
dują, że wykrywalność przypadków zatruć CO jest nadal niska. W krajach zachodnich szacuje się, że 30-50\% przypadków zatrucia $\mathrm{CO}$ pozostaje niezdiagnozowanych [3, s. 33-34].

Tlenek węgla powstaje w wyniku niecałkowitego spalania związków węgla spowodowanego niedostatecznym poziomem tlenu. Kuchenki gazowe, piece grzewcze, kotły, gazowe podgrzewacze wody są potencjalnymi źródłami tlenku węgla. Brak dostępu świeżego powietrza do pomieszczeń, w których znajdują się potencjalne źródła CO, powoduje zwiększoną koncentrację tego gazu w pomieszczeniu, co skutkować może zaczadzeniem. Należy zwracać szczególną uwagę na właściwą wentylację pomieszczeń: nie należy zamykać szczelnie okien czy likwidować otworów wentylacyjnych w drzwiach łazienkowych. Ważne, aby regularnie kontrolować drożność przewodów wentylacyjnych i kominowych [2].

Bezwonny, bezbarwny oraz niedrażniący tlenek węgla jest gazem szczególnie niebezpiecznym, ponieważ osoby narażone na jego działanie często nie są tego świadome. Najczęściej osoba zatruta tlenkiem węgla w chwili pojawienia się pierwszych objawów bagatelizuje je, pozostając nadal w pomieszczeniu z wysokim stężeniem CO. Dopiero znaczne nasilenie objawów zmusza osobę zatrutą do wyjścia na zewnątrz. Często traci ona przytomność i jeśli pomoc nie pojawi się w odpowiednim czasie, może dojść do śmierci.

Tlen w organizmie człowieka transportowany jest za pomocą krwinek czerwonych. Hemoglobina, białko erytrocytarne łączy się z tlenem, tworząc oksyhemoglobinę, i w tej postaci dociera do wszystkich tkanek i narządów. $\mathrm{W}$ przypadku zwiększonego stężenia $\mathrm{CO} \mathrm{w}$ powietrzu, gaz ten łączy się $\mathrm{z}$ metalobiałkami zawierającymi żelazo (hemoglobiną, mioglobiną, oksydazą cytochromową), wypierając $\mathrm{z}$ tych połączeń tlen. Powinowactwo tlenku węgla do hemoglobiny jest około 210 razy większe niż powinowactwo tlenu.

$$
\mathrm{HbO}_{2}+\mathrm{CO} \Leftrightarrow \mathrm{HbCO}+\mathrm{O}_{2}
$$

Wiązanie $\mathrm{CO}$ z hemoglobiną jest odwracalne. Dysocjacja karboksyhemoglobiny przebiega jednak dziesięć razy wolniej niż dysocjacja oksyhemoglobiny. Niekorzystny wpływ tlenku węgla związany jest też z jego właściwością, polegającą na zwiększaniu stabilności połączenia hemoglobiny z tlenem, pogorszenia ,oddawania" przez hemoglobinę tlenu do tkanek i narządów [4, s. 520-527].

W wyniku blokowania transportu i wydłużenia procesu dysocjacji oksyhemoglobiny dochodzi do niedotlenienia narządów, a w konsekwencji do ich uszkodzenia. Szczególnie wrażliwe na niedotlenienie są tak zwane narządy krytyczne - ośrodkowy układ nerwowy oraz mięsień sercowy. Ciężkie zatrucie tlenkiem węla powoduje demielinizację substancji białej, co prowadzi do obrzęku mózgu, a także bezpośrednio, niezależnie od hipoksji, uszkadza mięsień sercowy [5].

\section{Zatrucie tlenkiem węgla}

Objawy zatrucia tlenkiem węgla są nieswoiste i zależą między innymi od jego stężenia oraz czasu ekspozycji. Im dłużej poszkodowany przebywa w środowisku o wysokim stężeniu CO, tym poziom karboksyhemoglobiny w jego organizmie będzie wyższy. Utrata możliwości transportu tlenu przez krwinki czerwone spowoduje niedotlenienie tkanek i narządów. U osoby znajdującej się $\mathrm{w}$ środowisku $\mathrm{z}$ tlenkiem węgla $\mathrm{w}$ powietrzu następują:

- lekki ból głowy przy ekspozycji przez 2-3 godziny przy 00-200 ppm (0,01\%-0,02\%) CO;

- zawroty głowy, wymioty i konwulsje po 45 minutach wdychania, a po dwóch godzinach trwała śpiączka przy 800 ppm $(0,08 \%) \mathrm{CO}$;

- silny ból głowy, wymioty, po 20 minutach konwulsje, a po 2 godzinach zgon przy 1600 ppm $(0,16 \%) \mathrm{CO}$;

- ból głowy i wymioty po 1-2 minutach, a w niespełna 20 minut zgon przy 6400 ppm $(0,64 \%) \mathrm{CO}$;

- po 3 minutach następuje śmierć przy 12800 ppm $(1,28 \%) \mathrm{CO}[2]$.

Podobne objawy występują w wielu jednostkach chorobowych, co powoduje duże trudności diagnostyczne. Osoby po ekspozycji na tlenek węgla najczęściej zgłaszają dolegliwości neurologiczne: bóle i zawroty głowy, uczucie dezorientacji, a także zmęczenie czy osłabienie. Objawy zaostrzenia choroby niedokrwiennej serca, uczucie kołatania serca, duszność to objawy mogące mylnie sugerować schorzenia ze strony układu sercowo-naczyniowego. Wykaz objawów występujących po ekspozycji na tlenek węgla został przedstawiony poniżej w tabeli 1 .

Tabela 1.

Objawy ekspozycji na tlenek węgla [6, s. 270-272]

OBJAWY EKSPOZYCJI NA TLENEK WĘGLA OŚRODKOWY UKŁAD NERWOWY

\begin{tabular}{|c|}
\hline Niepamięć \\
\hline Dezorientacja \\
\hline Trudności z koncentracją \\
\hline Zawroty głowy \\
\hline Utrata Przytomności \\
\hline Bradykineza i drżenie spoczynkowe \\
\hline OBJAWY OGÓLNE \\
\hline Zmęczenie \\
\hline Osłabienie \\
\hline Znacząco dysharmonijne postawy lub zachowania \\
\hline Drgawki \\
\hline UKŁAD ŻOŁĄDKOWO-JELITOWY \\
\hline Ból (skurczowy) brzucha \\
\hline Biegunka \\
\hline Nudności/wymioty \\
\hline Zaburzenia rytmu serca \\
\hline Duszność \\
\hline Dyskomfort w klatce piersiowej przy najmniejszym \\
wysiłku, bóle w spoczynku \\
\hline
\end{tabular}


Table 1.

Symptoms of exposure to carbon monoxide

\begin{tabular}{|c|}
\hline $\begin{array}{c}\text { SYMPTOMS OF EXPOSURE TO CARBON } \\
\text { MONOXIDE }\end{array}$ \\
\hline CENTRAL NERVOUS SYSTEM \\
\hline Amnesia \\
\hline Confusion \\
\hline Concentration difficulty \\
\hline Dizziness \\
\hline Loss of consciousness \\
\hline Resting tremor \\
\hline GENERAL SYMPTOMS \\
\hline Fatigue \\
\hline Weakness \\
\hline Disharmony attitudes or behaviour \\
\hline Seizures \\
\hline GASTROINTESTINAL \\
\hline Nausea / vomiting \\
\hline Pain (systolic) abdominal \\
\hline Diarrhoea \\
\hline CARDIOVASCULAR SYSTEM \\
\hline Chest pain \\
\hline Arrhythmias \\
\hline Dyspnoea \\
\hline
\end{tabular}

Objawy kliniczne zatrucia tlenkiem węgla zależą między innymi od jego stężenia oraz od czasu ekspozycji. Im dłużej poszkodowany przebywał w pomieszczeniu z wysokim stężeniem $\mathrm{CO}$, tym będzie wyższy poziom karboksyhemoglobiny w jego organizmie. Utrata możliwości transportu tlenu przez krwinki czerwone powoduje niedotlenienie tkanek i narządów. Poszkodowani, u których objawy zatrucia będą bardziej nasilone oraz pojawią się wcześniej, to osoby z przewlekłymi chorobami układu krążenia oraz osoby z chorobami układu oddechowego. Do grupy wysokiego ryzyka zatruciem CO zalicza się również osoby starsze, dzieci i kobiety w ciąży. Zwiększoną wrażliwość na działanie tlenku węgla wykazują osoby z przewlekłymi chorobami układu oddechowego czy krwionośnego, z zaburzeniami w układzie krwiotwórczym (np. z niedokrwistością) i alkoholicy [11,12].

Objawy kliniczne zatrucia tlenkiem węgla w zależności od poziomu karboksyhemoglobiny zastały przedstawione poniżej w tabeli 2.

Miotonia, do której dochodzi w wyniku zatrucia tlenkiem węgla, jest szczególnie niebezpieczna, gdyż uniemożliwia przytomnej jeszcze osobie zatrutej $\mathrm{CO}$ wydostanie się z pomieszczenia [13]. Postępowanie na miejscu zdarzenia jest stosunkowo proste i powinno opierać się na wypracowanych procedurach. Poszkodowani podejrzani o zatrucie tlenkiem węgla to między innymi ofiary pożarów. Na miejscu zdarzenia jako pierwsza pojawia się najczęściej straż pożarna. Strażacy, oprócz działań gaśniczych, mają za zadanie ewakuację osób oraz w przypadku braku służb medycznych rozpoczęcie wstępnej stabilizacji, a także wstępne leczenie poszkodowanych. Zabezpie- czenie miejsca zdarzenia i ewakuacja poszkodowanego w bezpieczne miejsce są czynnościami priorytetowymi, albowiem bezpieczeństwo osoby ratującej jest najważniejsze. Działania ratunkowe w przypadku podejrzenia o zaczadzenie niezwiązane $\mathrm{z}$ pożarem można prowadzić na miejscu zdarzenia pod warunkiem zapewnienia wymiany powietrza w pomieszczeniu (otwarcie okien i drzwi). Dla ratownika jednak bezpieczniej jest, gdy ewakuuje poszkodowanego w miejsce bezpieczne, najlepiej ze stałym dostępem świeżego powierza.

Tabela 2.

Objawy kliniczne a stężenie karboksyhemoglobiny $(\mathrm{HbCO})$ we krwi [7, s. 71-75]

\begin{tabular}{|c|l|}
\hline $\begin{array}{c}\text { STĘ̇̇ENIE } \\
\text { CO }(\%)\end{array}$ & \multicolumn{1}{|c|}{ OBJAWY } \\
\hline $0-10$ & Brak objawów lub niewielkie pobudzenie \\
\hline $10-20$ & $\begin{array}{l}\text { Ból głowy, zawroty głowy, rozszerzenie } \\
\text { naczyń skóry }\end{array}$ \\
\hline $20-30$ & $\begin{array}{l}\text { Ból głowy, zawroty głowy, uczucie } \\
\text { znacznego zmęczenia }\end{array}$ \\
\hline $30-40$ & $\begin{array}{l}\text { Silne bóle i zawroty głowy, znaczne } \\
\text { osłabienie, zaburzenia orientacji, nudności, } \\
\text { wymioty, spadek ciśnienia tętniczego }\end{array}$ \\
\hline $40-50$ & Nasilające się objawy jak wyżej \\
\hline $50-60$ & $\begin{array}{l}\text { Znaczna tachykardia, zaburzenia } \\
\text { oddychania, sinica, głębokie zaburzenia } \\
\text { świadomości }\end{array}$ \\
\hline $60-70$ & $\begin{array}{l}\text { Śpiączka, drgawki, bradykardia, zwolnienie } \\
\text { oddechu, zgon }\end{array}$ \\
\hline
\end{tabular}

Table 2.

Clinical symptoms according to carboxyhemoglobin concentration

\begin{tabular}{|c|l|}
\hline $\begin{array}{c}\text { CO } \\
\text { CONCENTRATION } \\
(\%)\end{array}$ & \multicolumn{1}{|c|}{ SYMPTOMS } \\
\hline $0-10$ & No symptoms or slight agitation \\
\hline $10-20$ & $\begin{array}{l}\text { Headache, dizziness, skin } \\
\text { vasodilation }\end{array}$ \\
\hline $20-30$ & Headache, dizziness, feeling tired \\
\hline $30-40$ & $\begin{array}{l}\text { Strong headaches, dizziness, severe } \\
\text { weakness, disorientation, nausea, } \\
\text { vomiting, hypotension }\end{array}$ \\
\hline $40-50$ & Worsening symptoms as above \\
\hline $50-60$ & $\begin{array}{l}\text { A significant tachycardia, respiratory } \\
\text { distress, cyanosis, profound } \\
\text { disturbance of consciousness }\end{array}$ \\
\hline $60-70$ & $\begin{array}{l}\text { Coma, convulsions, bradycardia, } \\
\text { release the breath, death }\end{array}$ \\
\hline
\end{tabular}

Przy ocenie poszkodowanego istotne jest trzymanie się określonych zasad. Po zapewnieniu bezpieczeństwa sobie i poszkodowanemu kolejnym zadaniem ratownika medycznego jest sprawdzenie przytomności poszkodowanego. Po uklęknięciu przy poszkodowanym należy potrząsnać go za ramiona i głośno zapytać: „,czy wszystko w porządku?" [8, s. 74-93]. Procedura postępowania ratownika na miejscu zdarzenia została przedstawiona poniżej na rycinie 1 . 


\section{ZABEZPIECZENIE MIEJSCAZDARZENIA}

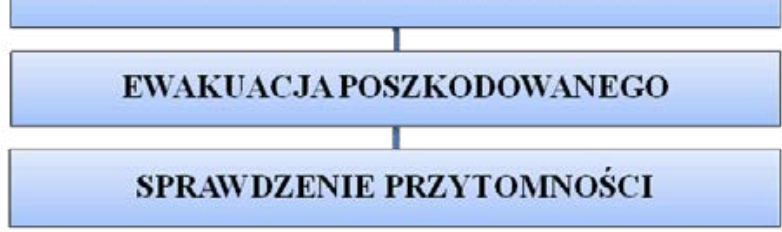

Ryc. 1. Postępowania ratownika na miejscu zdarzenia

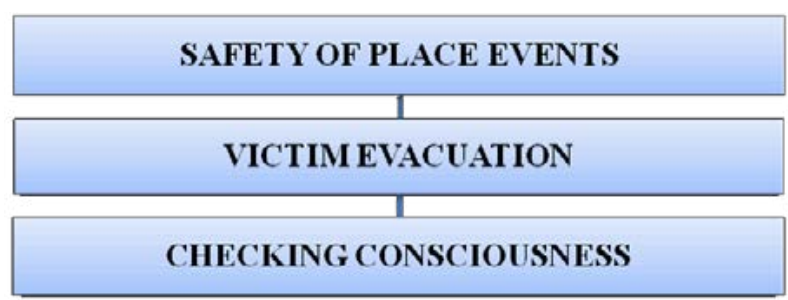

Fig. 1. Procedure paramedic at the scene

Wstępnej oceny stanu przytomności poszkodowanego należy dokonać z zastosowaniem skali AVPU lub GCS (ang. Glasgow Coma Scale), skali Glasgow. Skala AVPU opiera się na badaniu reakcji na bodźce zewnętrzne i określeniu kategorii stanu przez przyporządkowanie poszkodowanemu odpowiedniej litery:

A (ang. Alert) - oznacza poszkodowanego przytomnego, skupiającego uwagę;

$\mathbf{V}$ (ang. Verbal) - poszkodowany reaguje na polecenia głosowe;

$\mathbf{P}$ (ang. Pain) - reaguje na bodźce bólowe;

$\mathbf{U}$ (ang. Unresponsive) - nieprzytomny, nie reaguje na żadne bodźce.

Skala AVPU stosowana jest do wstępnej oceny przytomności.

Skala Glasgow służy do oceny poziomu przytomności i może być pomocna przy sprawdzaniu skuteczności prowadzonych działań przez ratownika. Stosując skalę Glasgow poddaje się ocenie według trzech kategorii: A, B, C. Kategoria A dotyczy otwierania oczu, B - kontaktu słownego, a litera $\mathrm{C}$ - reakcji ruchowej. Odpowiedź poszkodowanego w poszczególnych kategoriach jest oceniana w następujących skalach:

\section{A. Otwieranie oczu:}

4 punkty - spontaniczne;

3 punkty - na polecenie;

2 punkty - na bodźce bólowe;

1 punkt - nie otwiera oczu.

B. Kontakt słowny:

5 punktów - odpowiedź logiczna, pacjent zorientowany co do miejsca, czasu i własnej osoby;

4 punkty - pacjent zdezorientowany, splątany;

3 punkty - odpowiedź nieadekwatna (nie na temat) lub krzyk;

2 punkty - niezrozumiałe dźwięki lub pojękiwanie; 1 punkt - bez reakcji.

C. Reakcja ruchowa:

6 punktów - spełnianie ruchowych poleceń słownych lub migowych;

5 punktów - pacjent lokalizuje bodziec bólowy;
4 punkty - reakcja obronna na ból, wycofanie, próba usunięcia bodźca bólowego;

3 punkty - patologiczna reakcja zgięciowa, (przywiedzenie ramion, zgięcie w stawach łokciowych i ręki, przeprost w stawach kończyn dolnych);

2 punkty - patologiczna reakcja wyprostna, (odwiedzenie $\mathrm{i}$ obrót ramion do wewnątrz, wyprost w stawach łokciowych, nawrócenie przedramion i zgięcie stawów ręki, przeprost w stawach kończyn dolnych, odwrócenie stopy);

1 punkt - bez reakcji.

Poszkodowany przytomny w skali AVPU może być określony jako A, V, gdy reaguje na polecenia głosowe, lub P, jeśli reaguje tylko na bodźce bólowe. W skali Glasgow może otrzymać od 9-15 punktów. Pacjent nieprzytomny w skali AVPU określany jako U, w skali Glasgow może otrzymać od 3 do 8 punktów. Przyporządkowywanie poszkodowanemu liczby punktów lub liter nie powinno jednak opóźniać czynności ratunkowych wykonywanych przez ratownika na miejscu zdarzenia. Po ustabilizowaniu stanu pacjenta można przeanalizować i powtórnie określić poziom przytomności. Zastosowanie powyższych skal umożliwia obiektywne przekazanie informacji służbom medycznym przejmującym pacjenta, a także pozwala ocenić skuteczność prowadzonych działań.

\section{Postępowanie z poszkodowanym przytomnym}

Postępowanie z pacjentem przytomnym należy rozpocząc od podania tlenu. Tlen jest przechowywany w butlach takich lub podobnych do tej przedstawionej na rycinie 2 .

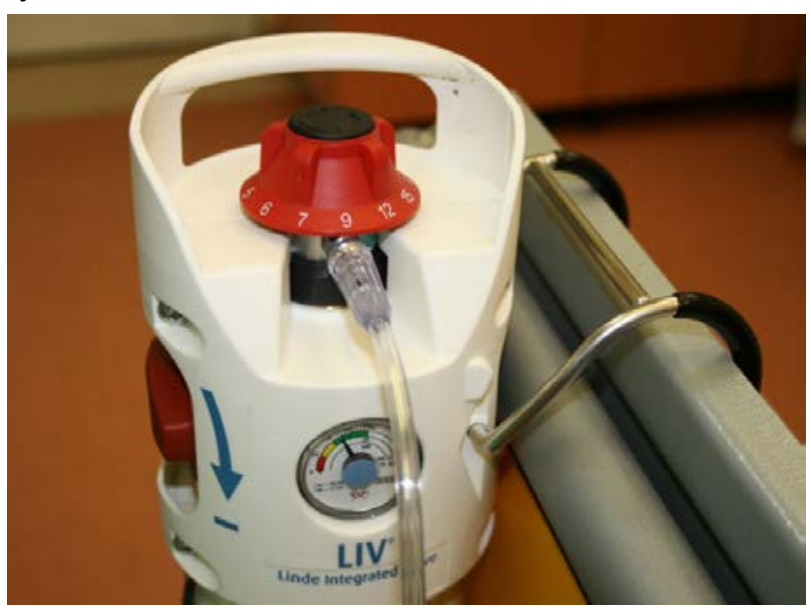

Ryc.2. Butla z tlenem (fot. K. Grobelska)

Fig. 2. Oxygens boutle

Tlen podaje się poszkodowanemu, wykorzystując maskę z rezerwuarem i workiem (ryc. 3). Optymalny przepływ tlenu to $8-12 \mathrm{l} / \mathrm{min}$. Do worka, z którego podczas wdechu pobierana jest mieszanina oddechowa, podłączone jest źródło tlenu. Poprzez maskę z rezerwuaru poszkodowany wdycha powietrze - mieszaninę gazów - z zawartością tlenu około $60-80 \%$ [9, s. 736-737]. Wydech następuje przez zastawkę jednokierunkową, która unie- 
możliwia wydychanemu powietrzu trafić ponownie do worka.

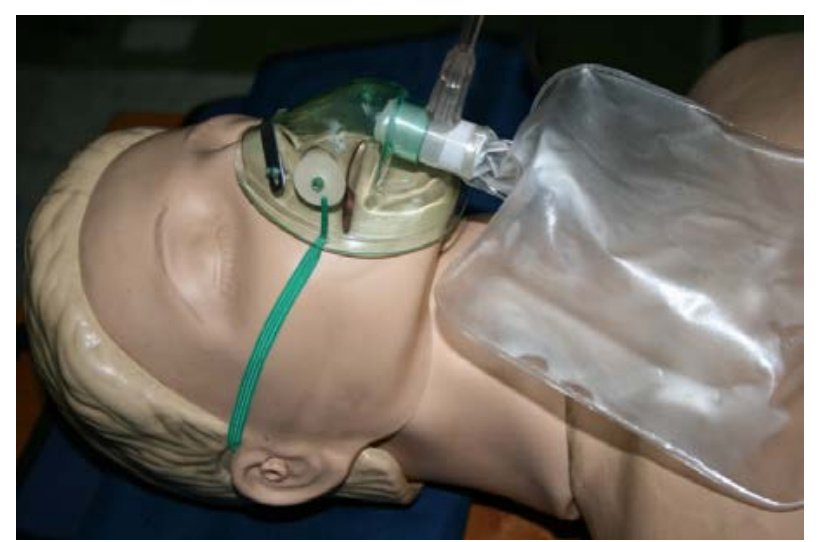

Ryc. 3. Maska twarzowa z rezerwuarem (fot. K. Grobelska)

Fig. 3. Facial mask with reservoir (fot. by K. Grobelska)

Gdy przeprowadzanie tlenoterapii jest niemożliwe, należy zapewnić poszkodowanemu dostęp świeżego powietrza, najlepiej wynosząc go na zewnątrz budynku.

U osób zatrutych tlenkiem węgla należy brać pod uwagę możliwość wystąpienia urazu. Szybkiemu badaniu urazowemu, według schematu BTLS (Basic Trauma Life Support), powinien być poddany każdy poszkodowany. Czynności diagnostyczne mają na celu szybkie wykrycie urazów zagrażających życiu poszkodowanego oraz w miarę możliwości ich wstępne zaopatrzenie. Badanie według schematu BTLS rozpoczyna się od głowy i szyi, poprzez klatkę piersiową, brzuch, miednicę, na kończynach dolnych i górnych kończąc. Jeżeli przed przystąpieniem do badania lub w jego trakcie wykryje się uraz zagrażający życiu lub zdrowiu, na przykład silne krwawienie, należy niezwłocznie je zaopatrzyć i powrócić do wykonywania czynności wg schematu BTLS. Poniżej został przedstawiony schemat (2) postępowania z poszkodowanym przytomnym.

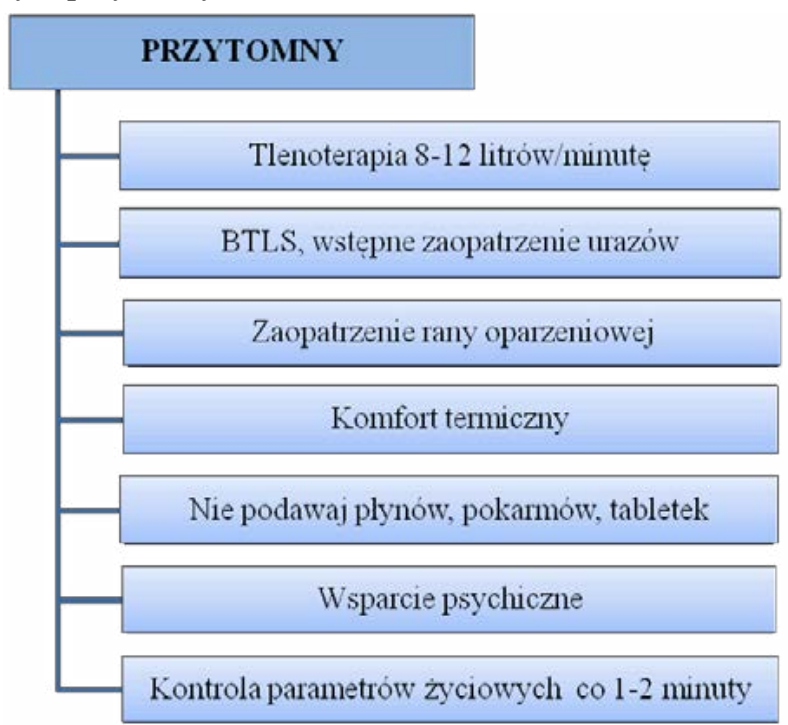

Ryc. 4. Postępowanie z poszkodowanym przytomnym

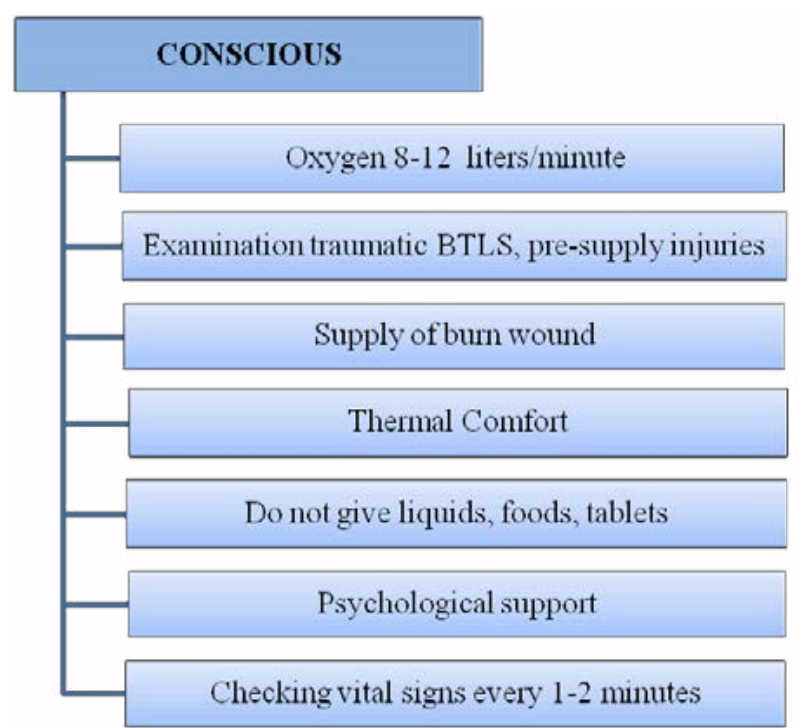

Fig. 4. Treatment of a conscious victim

Jeśli pozwala na to stan pacjenta, należy przeprowadzić z nim wywiad w celu uzyskania informacji przydatnych w badaniu i diagnostyce skutków urazu. SAMPLE jest to hasło (wyraz) zbudowane $\mathrm{z}$ pierwszych liter słów określających uporządkowany zakres informacji, które powinien uzyskać ratownik w drodze wywiadu z osobą poszkodowaną. Zachowanie kolejności SAMPLE (ryc. 5) ułatwia uzyskiwanie uporządkowanych informacji o poszkodowanym oraz o przyczynach zaistnienia zdarzenia [10, s. 24-31].

\begin{tabular}{|c|l|}
\hline LITERA & \multicolumn{1}{|c|}{ NAZWA } \\
\hline S & Symptomy (dolegliwości) \\
\hline A & Alergie (uczulenia) \\
\hline $\mathbf{M}$ & Medykamenty (stosowane leki) \\
\hline $\mathbf{P}$ & Przebyte choroby /ciąża \\
\hline L & Lunch - ostatni posiłek \\
\hline E & $\begin{array}{l}\text { Ewentualnie co się stało? (wydarzenia } \\
\text { poprzedzające wypadek) }\end{array}$ \\
\hline
\end{tabular}

Ryc. 5. Schemat badania SAMPLE [9]

\begin{tabular}{|c|l|}
\hline LETTER & \multicolumn{1}{|c|}{ NAME } \\
\hline S & Symptoms \\
\hline A & Allergies \\
\hline M & Medications \\
\hline P & Past disease / pregnancy \\
\hline L & Lunch - the last meal \\
\hline E & $\begin{array}{l}\text { Alternatively, what happened? (events before the } \\
\text { event) }\end{array}$ \\
\hline
\end{tabular}

Fig. 5. Test scheme SAMPLE [9]

Podczas badania urazowego należy stosować procedury adekwatne do stanu poszkodowanego, okoliczności niesienia pomocy oraz warunków panujących na miejscu zdarzenia. W przypadku podejrzenia urazu kręgosłupa 
u poszkodowanych przytomnych, niezależnie od stosowania tlenoterapii, należy rozważyć użycie kołnierza szyjnego lub deski ortopedycznej. Należy zaopatrzyć krwawienia zewnętrzne, w szczególności rany klatki piersiowej i brzucha oraz unieruchomić wbite, tkwiące w nich przedmioty.

Niezależnie od oceny i zabezpieczenia podstawowych czynności życiowych, a także szybkiego badania urazowego należy chronić poszkodowanego przed nadmiernym wychłodzeniem lub przegrzaniem. W przypadku niesprzyjających warunków otoczenia (niskiej temperatury, przemoczenia odzieży, braku ubrania, opadów deszczu itp.) w stanie nadmiernego wychłodzenia organizmu lub zagrożenia wychłodzeniem należy rozważyć prowadzenie działań ratunkowo-diagnostycznych w pomieszczeniu, zastosować koc ratunkowy lub inne okrycie dla ochrony poszkodowanego. W przypadku nadmiernego przegrzania organizmu lub zagrożenia przegrzaniem powinno się stosować wobec poszkodowanego środki zapobiegawcze (woda, lód) lub przenieść go, jeśli to możliwe, do pomieszczenia o niskiej temperaturze powietrza.

W trakcie prowadzenia działań ratunkowych, jeśli pozwalają na to okoliczności i stan poszkodowanego, należy informować poszkodowanego o podejmowanych czynnościach, jego stanie zdrowia, kolejnych czynnościach itd. Rozmowa z poszkodowanym i wsparcie psychiczne stanowią ważny element działań ratunkowych. Nie należy podawać poszkodowanemu płynów, produktów spożywczych lub leków, ponieważ jego stan może ulec pogorszeniu. Osoba zatruta CO, pomimo prowadzonych czynności ratunkowych, może stracić przytomność, a obecność płynu, pokarmu lub tabletek w żołądku zwiększa ryzyko zachłyśnięcia. W trakcie oczekiwania na przyjazd ambulansu pogotowia ratunkowego, należy pozostawać w kontakcie werbalnym z poszkodowanym i kontrolować jego czynności życiowe co 1-2 minuty.

\section{Postępowanie z poszkodowanym nieprzytomnym}

W sytuacji, gdy po sprawdzeniu, czy poszkodowany jest przytomny, stwierdza się brak reakcji, należy bezzwłocznie ocenić, czy poszkodowany oddycha. Sprawdzenie oddechu wykonuje się po udrożnieniu dróg oddechowych: odchyleniu głowy (nie należy stosować w przypadku podejrzenia urazu kręgosłupa) i uniesieniu żuchwy. Utrzymując drożność dróg oddechowych przez 10 sekund wzrokiem, słuchem i dotykiem, ocenia się, czy oddech u badanego jest prawidłowy, nieprawidłowy czy nieobecny.

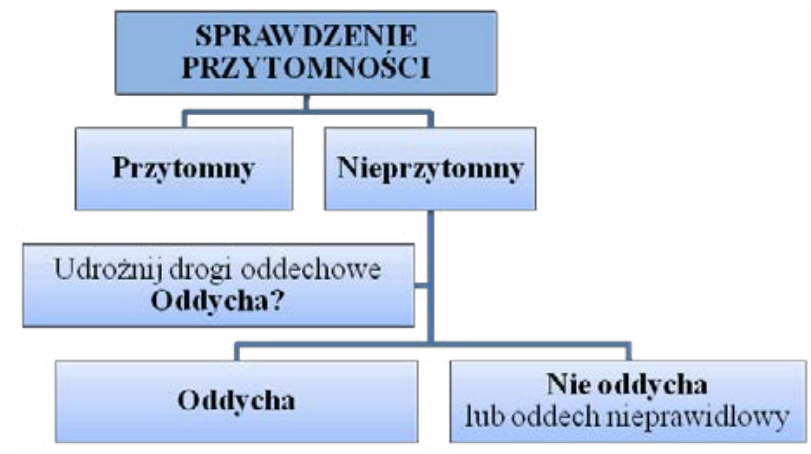

Ryc. 6. Schemat postępowania z pacjentem nieprzytomnym

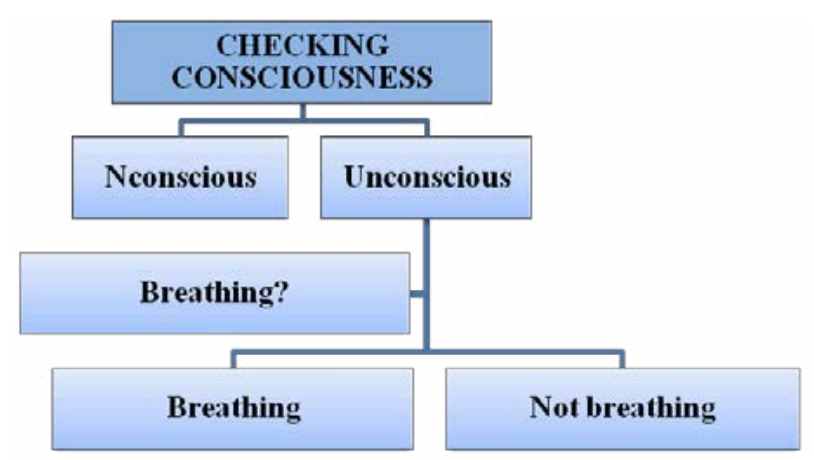

Fig. 6. Scheme the procedure with the patient unconscious

Po stwierdzeniu u poszkodowanego nieprzytomnego prawidłowego oddechu należy, podobnie jak w przypadku osoby przytomnej, zastosować tlenoterapię bierną, stosując maskę z rezerwuarem. W celu zapewnienia drożności dróg oddechowych u pacjentów nieprzytomnych można zastosować rurkę ustno-gardłową, która zapobiega przemieszczaniu się języka i podniebienia miękkiego ku tyłowi. Rozmiar rurki określa się, dobierając jej długość w odniesieniu do odległości od kącika ust do płatka ucha (ryc. 7. Należy pamiętać, że rurkę ustno-gardłową stosuje się tylko u pacjentów nieprzytomnych, u których zniesione są odruchy z tylnej ściany gardła.

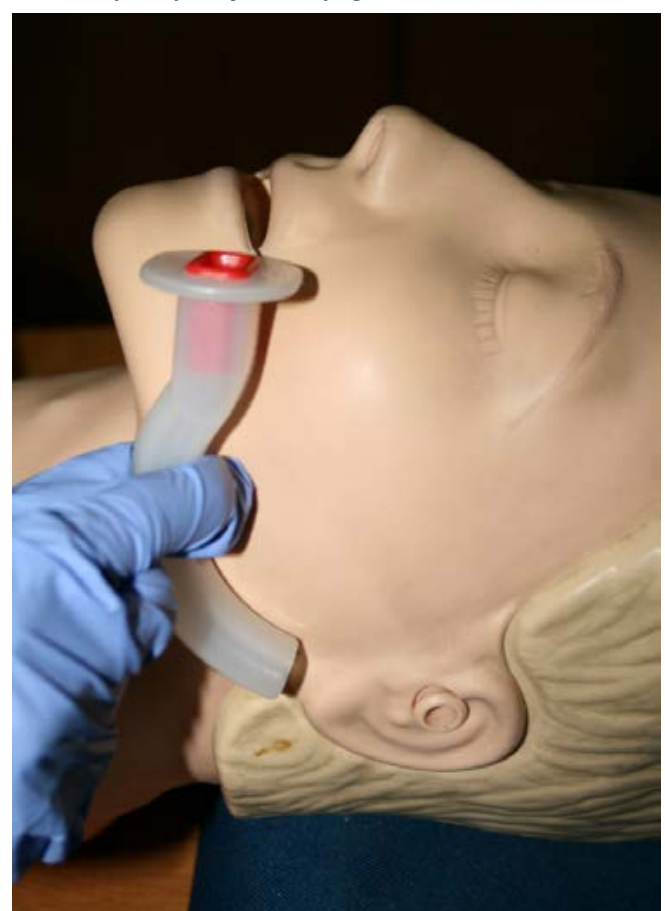

Ryc. 7. Metoda dopasowania rurki ustno-gardłowej (fot. K. Grobelska)

Fig. 7. Way of providing the oropharyngeal tube (fot. by K. Grobelska)

W celu zabezpieczenia nieprzytomnego przed zachłyśnięciem wymiocinami, a także w celu pośredniego udrożnienia dróg oddechowych, poszkodowanego układa się w pozycji bocznej. Nie ma idealnej uniwersalnej pozycji dla wszystkich poszkodowanych. Pozycja bezpieczna (ryc. 8) powinna być stabilna, a poszkodowany powinien leżeć na boku. Pozycja powinna umożliwiać podparcie głowy, ale też zapobiegać uciskowi na klatkę piersiową i nie powodować trudności w oddychaniu [8]. 


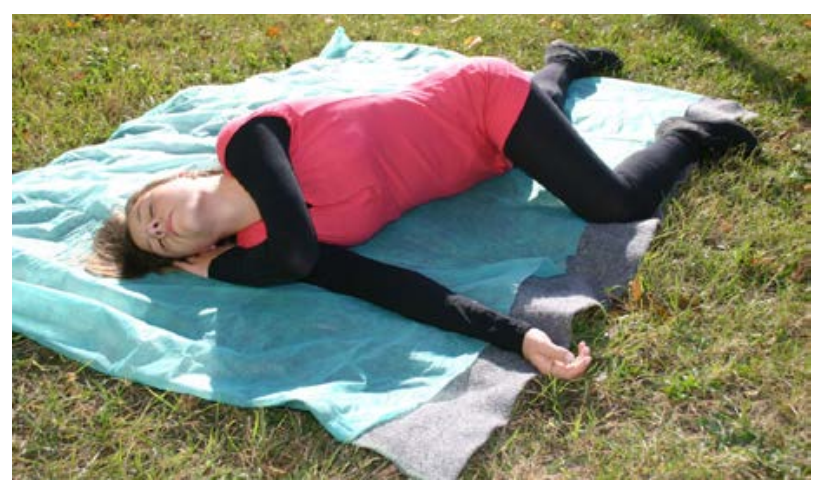

Ryc. 8. Pozycja bezpieczna (fot. E. Zieliński)

Fig. 8. Safe position (fot. by E. Zieliński)

W przypadku prowadzenia czynności wobec poszkodowanych nieprzytomnych, w oczekiwaniu na przybycie zespołu ratownictwa medycznego, należy zwracać szczególną uwagę na zabezpieczenie ich przed wychłodzeniem lub przegrzaniem oraz na kontrolę czynności życiowych (co 1-2 min). Postępowanie z poszkodowanym nieprzytomnym i oddychającym (ryc. 9) kończy się z chwilą przekazania ZMR.

\section{NIEPRZYTOMNY ODDYCHA}

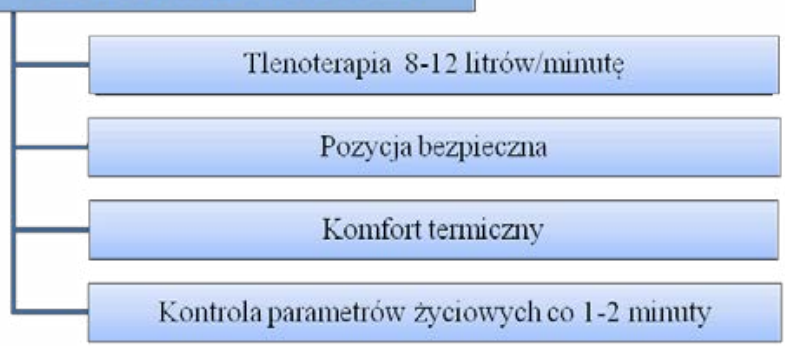

Ryc. 9. Postępowanie z poszkodowanym nieprzytomnym, oddychającym

\section{UNCONSCIOUS, BREATHING}

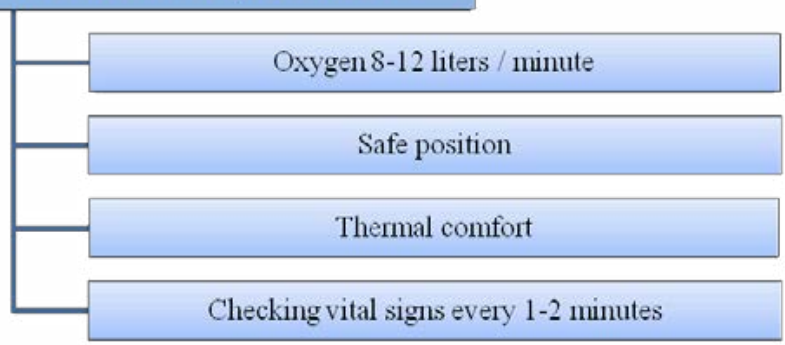

Fig. 9. Treatment of unconscious breathing victim

Można również spotkać się z sytuacją, w której nieprzytomna ofiara zatrucia tlenkiem węgla nie będzie oddychać lub jej oddech będzie nieprawidłowy. Należy wówczas postępować zgodnie z Wytycznymi 2010 Europejskiej Rady Resuscytacji, stosując BLS (Basic Life Support) podstawowe czynności resuscytacyjne. Osobom poszkodowanym z zatrzymaniem krążenia należy wykonywać uciśnięcia klatki piersiowej. Wczesne podjęcie resuscytacji krążeniowo-oddechowej zwiększa szanse przeżycia osób, u których doszło do zatrzymania krążenia, nawet jeśli będzie to tylko uciskanie klatki piersiowej. Resuscytację krążeniowo-oddechową należy prowadzić do momentu przyjazdu służb ratowniczych. Ratownicy lub osoby nieprzeszkolone powinny udzielać pomocy, nieza- leżnie od kwalifikacji, wiedzy i umiejętności. Nie powinno się unikać prowadzenia resuscytacji krążeniowo-oddechowej, a brakującą wiedze na temat jej prowadzenia można zdobywać w dowolny sposób np. z Internetu, przekazu werbalnego bezpośredniego lub pośredniego (telefonicznego), instrukcji, podręczników itp. [8]

Uciskanie klatki piersiowej powinno być wykonywane przez ratownika znajdującego się w pozycji klęczącej przy boku leżącego, na wznak poszkodowanego. Jeżeli nie ma istotnych przeciwwskazań, ratownik dowolnie wybiera stronę osoby ratowanej, po której klęka. Nadgarstek jednej ręki powinien znaleźć się na środku klatki piersiowej, tj. dolnej połowy mostka osoby poszkodowanej. Nadgarstek drugiej ręki powinien znaleźć się na grzbiecie dłoni leżącej na klatce piersiowej w taki sposób, aby można było zapleść ich palce. Ramiona ratownika mają być wyprostowane w pozycji prostopadłej do klatki piersiowej poszkodowanego. Nacisk ma być kierowany na mostek a nie na żebra poszkodowanego, nie należy także uciskać górnej części brzucha ani dolnego końca mostka [8].

Osoby prowadzące resuscytację krążeniowo-oddechową powinny dążyć do jak najwyższej jakości wykonywanych czynności ratunkowych. Standard stanowi częstotliwość 100-120 uciśnięć klatki piersiowej na minutę z siłą pozwalającą osiagać głębokość 5-6 cm. Po każdym ucisku powinno się dopuścić do pełnego powrotu klatki piersiowej do pierwotnego, naturalnego kształtu. Przerwy w uciskaniu klatki piersiowej mają być jak najkrótsze. Ratownicy lub osoby przeszkolone powinny wykonywać wentylację płuc w sekwencji 30 uciśnięć do 2 oddechów. W praktyce, z powodu przerw koniecznych do wykonania oddechów ratowniczych, liczba uciśnięć wykonanych w ciągu jednej minuty resuscytacji krążeniowo-oddechowej jest mniejsza niż 100. Nie powinna jednak spadać poniżej 60 uciśnięć [8].

Postępowanie z osobą poszkodowaną nieprzytomną i nieoddychającą zostało przedstawionej poniżej na rycinie 10 .

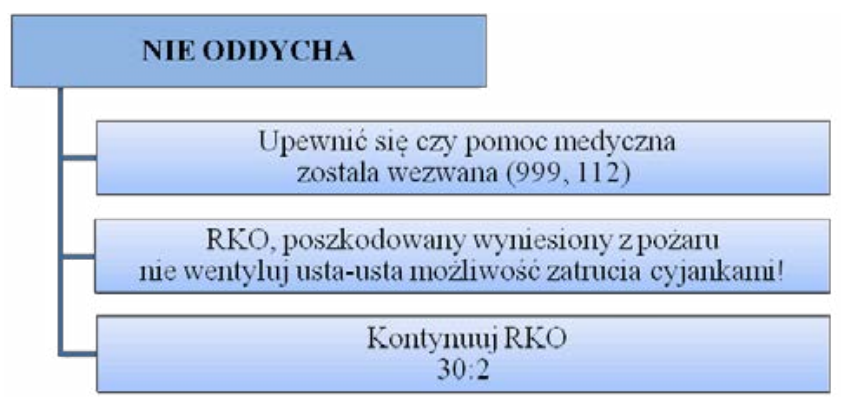

Ryc. 10. Postępowanie z poszkodowanym nieprzytomnym, nieoddychającym

\section{NOT BREATHING}

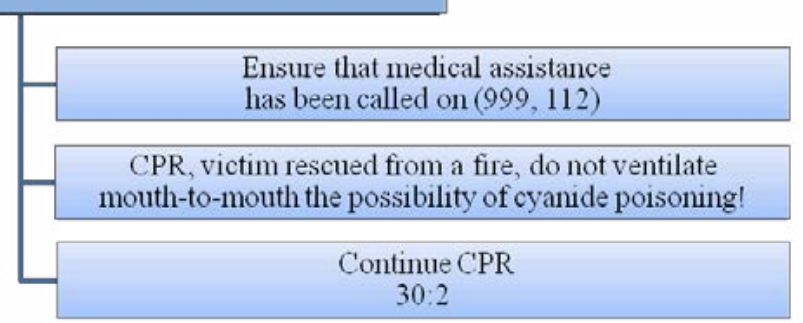

Fig. 10. Treatment of unconscious, not breathing victim 
Po upewnieniu się, że zespół ratownictwa medycznego został wezwany, należy rozpocząć resuscytację krążeniowo-oddechową, zaczynając od pięciu oddechów ratunkowych. Wytyczne 2010 Europejskiej Rady Resuscytacji nie rekomendują stosowania pięciu oddechów ratunkowych w przypadku zatrzymania krążenia wskutek urazu lub zatrucia przez osoby bez wykształcenia medycznego. Ma to związek z założeniem, że osoby nie mające doświadczenia w rozpoznawaniu takich przypadków nie powinny wykonywać tych czynności. Poszkodowany wyniesiony z pożaru może być zatruty również cyjankami. Przy podejrzeniu takiego zatrucia nie należy wentylować poszkodowanego metodą usta-usta. W przypadku dysponowania workiem samorozprężalnym $\mathrm{z}$ rezerwuarem należy go użyć z podłączonym tlenem, a w przypadku jego braku prowadzić resuscytację krążeniowo-oddechową, uciskając jedynie klatkę piersiową. Sposób wentylacji workiem samorozprężalnym $\mathrm{z}$ rezerwuarem został przedstawiony poniżej na rycinie 11 .

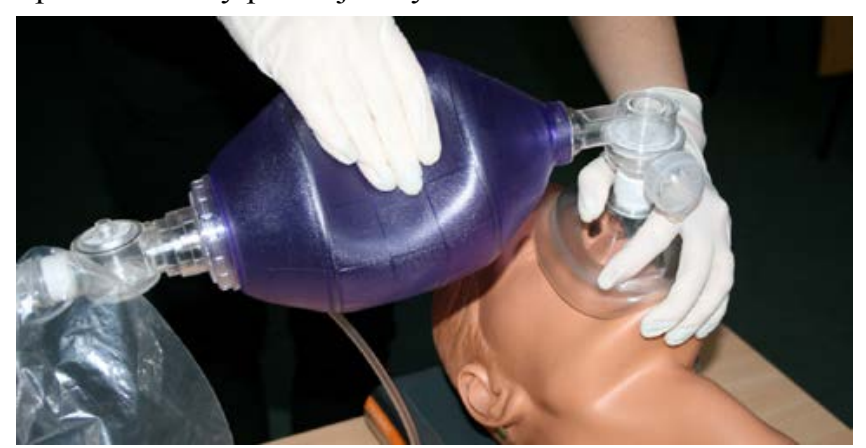

Ryc. 11. Wentylacja workiem samorozsprężalnym z rezerwuarem (fot. K. Grobelska)

Fig. 11. Ambu bag ventilation (fot. by K. Grobelska)

Podczas oczekiwania na przyjazd ambulansu ratownictwa medycznego powinno się nieprzerwanie prowadzić czynności reanimacyjne. W celu efektywnego wykorzystania sił ratowników należy dokonywać zmian co około 2 minuty. W przypadku zatrutych tlenkiem węgla nie można wykluczyć przyczyny sercowej zatrzymania krążenia. Przy dostępności AED (Automated External Defibrillator), automatycznego defibrylatora zewnętrznego, nie przerywając uciśnięć klatki piersiowej, należy niezwłocznie przykleić elektrody do klatki piersiowej osoby poszkodowanej, a następnie wykonywać czynności zgodnie z instrukcją dołączoną do tego urządzenia. W celu zapewnienia komfortu termicznego poszkodowanemu nieprzytomnemu powinno się stosować, podobnie jak przytomnej osobie zatrutej $\mathrm{CO}$, środki zapobiegające hipotermii lub udarowi cieplnemu [14].

\section{Podsumowanie}

Tlenek węgla to wciąż niedoceniany „,cichy zabójca”. Pomimo licznych akcji prewencyjnych prowadzonych przez funkcjonariuszy Państwowej Straży Pożarnej wciąż odnotowuje się dużą liczbę wypadków zatrucia czadem. Zatrucia tlenkiem węgla to również duży problem diagnostyczny. Nieswoistość objawów u zatrutych pacjentów skutkuje niską rozpoznawalnością. Postępowanie z poszkodowanym na miejscu zdarzenia, a także w szpitalu jest często niewłaściwe, a diagnostyka obejmuje naj- częściej choroby układu krążenia lub centralnego układu nerwowego. W pracy zaproponowano schemat postępowania ratownika na miejscu zdarzenia. Biorąc pod uwagę stan poszkodowanego, wyodrębniono trzy ścieżki czynności ratunkowych. Postępowanie z zatrutym przytomnym polega $\mathrm{w}$ pierwszej kolejności na zapewnieniu mu dostępu świeżego powietrza, a w miarę możliwości zastosowaniu tlenoterapii. Należy pamiętać o badaniu urazowym według schematu BTLS i wstępnym zaopatrzeniu urazów zagrażających życiu, a także komforcie termicznym oraz wsparciu psychologicznym poszkodowanego. Osoba zatruta nieprzytomna, która oddycha prawidłowo, wymaga, po włączeniu tlenoterapii i zastosowaniu pozycji bocznej, kontroli parametrów życiowych co 1-2 minuty, ponieważ jej stan może ulec pogorszeniu. W przypadku braku oddechu ratownik podejmuje czynności resuscytacyjne według Wytycznych 2010 Europejskiej Rady Resuscytacji, oczekując na przyjazd i przekazanie osoby zatrutej zespołowi ratownictwa medycznego.

Przedstawiony w niniejszym opracowaniu schemat postępowania z osobą zatrutą tlenkiem węgla może ułatwić podejmowanie właściwych decyzji i zwiększyć skuteczność działań ratowniczych na miejscu zdarzenia.

\section{Literatura}

1. www.stat.gov.pl [dostęp 12.03.2013]

2. www.straz.gov.pl [dostęp 12.03.2013]

3. Bauer K., Borysiewicz A., Wojewódzka-Żelezniakowicz M., Sawicki Z., Ładny R. J., Funkcjonowanie nowych zasad systemu ratownictwa medycznego oraz podejmowanie czynności resuscytacyjnych przez świadków zdarzenia na podstawie ankiety opinii pracowników pogotowia ratunkowego, w: J. Jakubaszko (red.), Medycyna Ratunkowa w Polsce. Zima 2009, Polskie Towarzystwo Medycyny Ratunkowej, Wrocław 2009.

4. Toksykologia. Podręcznik dla studentów lekarzy i farmaceutów, Seńczuk W. (red.), Wydawnictwo Lekarskie PZWL, Warszawa 2002.

5. www.pctox.pl [dostęp 12.03.2013]

6. Blumenthal I., Carbon monoxide poisoning, "JR Soc Med.", 2001.

7. Burda P., Ostre zatrucia, Medical Tribune Polska, Warszawa 2012.

8. Wytyczne 2010 Europejskiej Rady Resuscytacji, tłum. Polska Rada Resuscytacji, Kraków, 2010.

9. Dunn P. F. (red. nauk.), Szreter T. (red. pol.), Procedury kliniczne $w$ anestezjologii, MediPage, 2011.

10. Campbell E. J. (red.), Basic Trauma Life Support, „Medycyna Praktyczna", Kraków, 2006.

11. Procedury kliniczne $w$ anestezjologii, Dunn P. F. (red. nauk.), Szreter T. (red. pol.), MediPage, 2011.

12. Thom S.R., Carbon Monoxide pathophysiology and treatment, [w:] T.S. Neuman, S.R. Thom (red.), Physiology and Medicine of Hyperbaric Oxygen Therapy, Elsevier Inc., Philadelphia, 2008, pp. 321-347.

13. Sohn Y.H., Carbon monoxide poisoning. Encyclopedia of Movement Disorders 2010, pp. 187-189.

14. Norkool D.M., Kirkpatrick J.N., Treatment of acute carbon monoxide poisoning with hyperbaric oxygen. A review of 115 cases, "Ann Emerg Med", Volume 14, Issue 12, 1985, pp. 1168-1171.

15. pl.wikipedia.org [dostęp 16.05.2014]. 
lek. med. Kinga Grobelska - lekarz specjalista medycyny ratunkowej w Klinice Medycyny Ratunkowej Szpitala Uniwersyteckiego nr 1 w Bydgoszczy, asystent w Katedrze Medycyny Ratunkowej i Katastrof Collegium Medicum w Bydgoszczy UMK w Toruniu, kierownik ds. medycznych Centrum Hiperbarii Tlenowej i Leczenia Ran w Bydgoszczy, lekarz koordynator Wojewody Kujawsko-Pomorskiego w Bydgoszczy.

dr Anna Królikowska - pracownik Katedry i Zakładu Opieki Paliatywnej Collegium Medicum w Bydgoszczy, Uniwersytetu Mikołaja Kopernika w Toruniu, Kliniki Geriatrii i Hospicjum Domowego im. Ks. Jerzego Popiełuszki w Bydgoszczy. dr Ewa Zieliński - instruktor wykładowca w Bydgoskiej Szkole Wyższej, instruktor wykładowca, ratownik medyczny w Klinice i Katedrze Medycyny Ratunkowej Collegium Medicum w Bydgoszczy Uniwersytetu Mikołaja Kopernika w Toruniu, przewodnicząca Komisji Zarządzania (2008-2013) i kierownik szkoleń z zakresu Kwalifikowanej Pierwszej Pomocy (od 2007) Wodnego Ochotniczego Pogotowia Ratunkowego.

dr Jerzy Telak - pracownik Wydziału Inżynierii Bezpieczeństwa Cywilnego Szkoły Głównej Służby Pożarniczej w Warszawie, doktor w dziedzinie nauk społecznych, w dyscyplinie nauki o bezpieczeństwie. Delegat na Walne Zgromadzenie International Life Saving Federation, wiceprezydent ILS Federation of Europe, członek Rady ds. Ratownictwa Górskiego i Wodnego przy Ministrze Spraw Wewnętrznych (2008-2014), Prezes WOPR (2001-2014). 